\title{
GYAKUSETSU NO SETSUZOKUSHI SEBAGAI PENANDA WACANA PADA KORAN ASAHI ONLINE EDISI APRIL 2019
}

\author{
I.A.I.K.Dewi ${ }^{1}$, K.E.K.Adnyani ${ }^{2}$, G.S. Hermawan ${ }^{3}$ \\ ${ }^{123}$ Jurusan Pendidikan Bahasa Asing, Universitas Pendidikan Ganesha, Singaraja \\ e-mail: ika.kusuma@undiksha.ac.id, krishna.adnyani@undiksha.ac.id, satya.hermawan@undiksha.ac.id
}

\begin{abstract}
Abstrak
Penelitian ini bertujuan untuk mengidentifikasi konjungsi jenis gyakusetsu yang serta menganalisis fungsi gyakusetsu yang sebagai penanda wacana terdapat pada koran asahi online edisi April 2019. Subjek yang digunakan pada penelitian ini adalah koran asahi online yang terbit pada bulan April 2019. Penelitian ini merupakan penelitian deskriptif kualitatif dengan menggunakan kartu data. Teori yang digunakan adalah teori gyakusetsu menurut Makino (1995), teori setsuzokushi menurut Hirai Masao (1989), teori analisis wacana menurut (Stubbs, 1983), dan teori penanda wacana menurut (Nakajima, 2009). Hasil dari penelitian ini yaitudari 61 wacana artikel, ditemukan 7 bentuk gyakusetsu yaitu shikashi, demo, tokoroga, daga, tada, tadashi dan soredemo. Dari ketujuh bentuk gyakusetsu tersebut ditemukan 6 fungsi penanda wacana yaitu fungsi sebagai koherensi wacana, pembatas wacana, penanda kelanjutan, menarik minat atau perhatian pembaca, menandai proses berpikir, dan menunjukkan keraguan. Dari 7 bentuk gyakusetsu yang paling banyak ditemukan adalah shikashi dan yang paling sedikit adalah tokoroga. Selain itu, fungsi yang paling banyak ditemukan adalah sebagai koherensi wacana dan yang paling sedikit adalah menunjukkan keraguan.
\end{abstract}

Kata kunci: Gyakusetsu, konjungsi, penanda wacana, wacana

要旨

本論は 2019 年の4月オンライン朝日新聞に逆接の接続詞を分析する。その逆接の談話標議としての 機能について述べたものである。対象は２０１９年の4月オンライン朝日新聞である。また、本研究の 方法は質的研究でデーターカードを使用した。研究の結果は 61 談話にしかし、でも、ところが、だ が、ただ、ただし、それでもの 7 つの逆接が認められた。その 7 つの逆接が 6 つの談話標議が持って いる。それは談話のコヒーレンス、談話制限、続き、興味を引く、筆者の考え方、疑問の現れ方であ る。6つ談話標議の中に談話のコヒーレンスが一番多い。また、疑問の現れ方が一番少ない。

キーワード：逆接、接続詞、談話標議、談話

\section{Pendahuluan}

Wacana merupakan unsur bahasa yang berupa rentetan kalimat yang berkaitan, yang menghubungkan proposisi yang satu dengan proposisi lainnya, membentuk satu kesatuan, sehingga terbentuklah makna yang serasi di antara kalimat-kalimat itu (J.S Badudu, 2000 dalam Badara, 2012). Dalam wacana terdapat rentetan kalimat yang membentuk satu kesatuan paragraf, tetapi dalam menghubungkan antar kalimat diperlukan adanya satu unit bahasa tertentu untuk mengaitkannya. Oleh karena itu, dalam suatu wacana terdapat penanda wacana untuk mengaitkan antar kalimat atau paragraf. Unit bahasa yang berfungsi sebagai penyambung yaitu konjungsi atau kata sambung. Dalam bahasa jepang disebut dengan setszokushi.

Setsuzokushi digunakan dalam beberapa media tulis seperti koran, novel, komik, dan media lainnya. Salah satu dari media tulis tersebut yaitu wacana koran yang dipilih sebagai subjek dari penelitian ini. Hal ini karena penjelasan faktualnya menunjukkan sisi kognitif yang beragam dari penulis. Hal ini berbeda dengan komik atau novel karena lebih kearah fiksi dan disusun oleh satu orang. Sedangkan, artikel pada koran bisa ditulis oleh wartawan yang berbeda-beda dengan sudut pandang yang berbeda juga sehingga dari hal tersebut dapat mengetahui cara pengungkapan orang Jepang dilihat dari contoh yang berbeda-beda.

Penelitian ini menggunakan koran Asahi online sebagai sumber untuk menganalisis setsuzokushi. Hal ini karena koran asahi telah banyak pendapatkan penghargaan seperti 
berada pada tingkat tertinggi sebagai koran yang diminati oleh para pelajar menurut hasil survei dari comprehensive national newspaper pada tahun 2017.

Terdapat berbagai jenis-jenis setsuzokushi yang dibagi menjadi 7 jenis menurut Hirai dalam Sudjianto (2004:171) yaitu hireisetsu no setsuzokushi, sentaku no setsuzokushi, tenka no setsuzokushi, gyakusetsu no setsuzokushi, junsetsu no setsuzokushi, tenkan no setsuzokushi, dan hosetsu no setsuzokushi. Dalam penelitian ini lebih fokus pada penggunaan gyakusetsu no setsuzokushi yaitu kata sambung untuk menyambungkan kalimat yang berlawanan. Konjungsi gyakusetsu perlu dianalisis karena pada koran asahi, gyakusetsu tidak hanya menghubungkan kalimat berlawanan saja tetapi juga memiliki fungsi yang berbeda seperti menyatakan opini. Oleh karena itu penelitian mengenai gyakusetsu no setsuzokushi sebagai penanda wacana pada koran asahi online April 2019 ini menarik untuk dikaji lebih lanjut.

\section{Setsuzokushi}

Ogawa (1982 dalam Ningtyas, 2017) yang menjelaskan definisi dari setsuzokushi yaitu salah satu jenis kelas kata dalam bahasa Jepang yang digunakan untuk menggabungkan dua kata atau lebih, klausa dengan klausa, dari penggabungan tersebut menunjukan hubungan antara isi ungkapan kalimat pertama dengan kalimat kedua, dan juga berfungsi untuk mengembangkan kalimat yang dirangkaikan oleh setsuzokushi tersebut.

Jenis-jenis setsuzokushi menurut Hirai dalam Sudjianto (2004:171) yaitu hireisetsu no setsuzokushi, sentaku no setsuzokushi, tenka no setsuzokushi, gyakusetsu no setsuzokushi, junsetsu no setsuzokushi, tenkan no setsuzokushi, dan hosetsu no setsuzokushi.

\section{Gyakusetsu no setsuzokushi}

\section{a. Daga}

Daga memiliki arti 'tetapi', 'namun', 'namun demikian'. Adapun ciri-ciri dari daga yaitu (1) konjungsi ini mengekspresikan hal kontras atau berlawanan dengan kalimat sebelumnya. (2) Dalam bahasa lisan, konjungsi daga tidak digunakan, tetapi diganti dengan menggunakan demo atau keredomo. Dalam bahasa formal desuga dapat digunakan secara lisan atau tulisan (Makino, 1995:18).

\section{b. Tokoroga}

Konjungsi tokoroga memiliki arti 'tetapi', 'namun'. Konjungsi ini digunakan untuk menyatakan fakta yang telah terjadi atau sesuatu yang berupa fakta ketika ada hal lain yang diharapkan. Beberapa ciri-ciri dari tokoroga yaitu (1) konjungsi tokoroga selalu muncul pada awal kalimat. (2) Kalimat ${ }_{1}$. Tokoroga kalimat ${ }_{2}$, pada kalimat kedua menunjukkan sesuatu yang tidak diharapkan dari kalimat pertama. (3) Kalimat yang mengikuti tokoroga adalah kalimat yang tidak diharapkan oleh pembicara (Makino, 1995).

\section{c. Shikashi}

Shikashi memiliki arti 'tetapi '. Konjungsi ini digunakan untuk memisahkan kalimat sebelumnya dengan kalimat berikutnya yang maknanya saling berlawanan. Selain itu, shikashi digunakan dalam bentuk formal. Shikashi memiliki kesamaan cara menghubungkan kalimat dengan tokoroga, demo, daga yaitu muncul pada awal kalimat (Makino, 1995).

\section{d. Tada}

Tada adalah konjungsi yang memisahkan kalimat berlawanan. Konjungsi ini digunakan saat pembicara atau penulis menerima sebagian pernyataan atau hanya menerima kalimat $_{1}$ saja (Makino, 1995).

\section{e. Tadashi}

Tadashi digunakan untuk memisahkan kalimat berlawanan. Konjungsi ini digunakan saat pembicara ingin menambahkan penjelasan tambahan, kondisi, ataupun pengecualian (Makino, 1995).

\section{f. Demo}

Demo memiliki arti 'tetapi', digunakan untuk memisahkan kalimat. Konjungsi ini digunakan dalam nonformal atau bentuk percakapan. Demo juga memiliki kesamaan ciri 
dengan konjungsi shikashi, daga, tokoroga, keredomo yaitu berada pada awal kalimat (DIJG, 1995)

\section{g. Soredemo}

Konjungsi soredemo memiliki arti 'namun', 'meskipun demikian', 'tetapi terlepas dari itu'. Ciri-ciri dari soredemo digunakan untuk (1) memisahkan kalimat sebelumnya dengan kalimat selanjutnya yang maknanya berlawanan. (2) Konjungsi ini juga berfungsi untuk mengeksperikan terlepas dari keadaan yang ada pada kalimat sebelumnya. (3) Terdapat sesuatu yang mengejutkan dimana berlawanan dengan kalimat sebelumnya. Jika makna dasar tersebut tidak ada, maka soredemo tidak dapat digunakan

\section{Analisis Wacana}

Menurut Stubbs, analisis wacana merupakan suatu kajian yang meneliti atau menganalisis bahasa yang digunakan secara alamiah baik dalam bentuk lisan ataupun tulisan. Alat wacana yang digunakan adalah (1) konjungsi, alat untuk menghubungkan bagian-bagian kalimat, atau paragraf dengan paragraf sehingga hubungan menjadi lebih eksplisit dan akan lebih jelas bila dibandingkan dengan hubungan yang tanpa konjungsi. (2) Kata ganti orang sebagai rujukan anaforis, sehingga kalimat yang sama tidak perlu diulang. (3) Menggunakan ellipsis yaitu penghilangan bagian kalimat yang sama yang terdapat dalam kalimat lain sehingga menjadi lebih efektif. (4) Menggunakan sebab akibat diantara isi kedua bagian kalimat, atau isi antara dua kalimat dalam satu wacana (Chaer, 2003).

\section{Penanda Wacana dalam Bahasa Jepang}

Dalam bahasa Jepang penanda wacana memiliki berbagai macam termasuk kata sambung (sorede, demo), adverbia (maa..), interjeksi (na..), atau kata ganti tunjuk (ano). Kategori penanda wacana dalam bahasa Jepang sangat luas, dilihat dari kelas kata yang berbedabeda. Fungsi penanda wacana menurut Nakajima (2009) yaitu (1) memberi tanda batasbatas pada wacana, menunjukkan bagian awal dari suatu wacana hingga akhir, (2) Menandakan awal dari ujaran, kelanjutan atau perbaikan, (3) Mengisi jeda, memberikan kelancaran, dan koherensi wacana, (4) Memunculkan perhatian, minat terhadap lawan bicara, (5) Mengungkapkan proses kognitif pada pemikiran pembicara, (6) Menunjukkan perhatian pendengar, (7) Menyiratkan keraguan.

\section{Metode}

Dalam tahap pengumpulan data digunakan metode simak. Metode simak adalah metode yang dilakukan dengan menyimak pemakaian bahasa (Surdyanto, 1993 dalam Nusantari, 2016). Penelitian ini juga menggunakan teknik catat. Teknik catat adalah teknik yang dilakukan dengan mencatat data-data yang telah disimak lalu dilanjutnya dengan pengklasifikasian data (Surdyanto, 1993 dalam Nusantari, 2016).

Data dianalisis dengan menggunakan teknik baca markah. Teknik baca markah adalah teknik analisis data dengan cara "membaca pemarkah" dalam suatu konstruksi. Teknik ini digunakan untuk menentukan peran konstituen kalimat (Kesuma, 2007 dalam Tiarasati, 2013). Dalam analisis data juga menggunakan teknik reduksi data. Reduksi data merupakan merangkum, memilih hal-hal pokok, memfokuskan pada hal-hal yang penting, dicari tema dan polanya (Sugiyono, 2012).

\section{Hasil dan Pembahasan}

Pada penelitian ini ditemukan 61 wacana pada koran asahi online edisi April yang memiliki gyakusetsu dan open accsess. Dalam 61 wacana ditemukan 78 gyakusetsu dengan 7 bentuk yaitu shikashi (23), demo (13), tokoroga (2), tada (18), daga (15), tadashi (1), dan soredemo (6).

Berikut data artikel wacana yang dianalisis. 


\section{Data 1}

Gōru mae de FW satō kō kara surūpasu o ukeru to, ochitsuite migiashi de gōru migi e nagashikonda.

Sakuki kyū seichō shi, konki mo 2 tokuten o agete iru. Shikashi, koko 4 shiai wa hidariashi no futomomo o fushō shite benchi o hazurete ita. 'Detara kekka o dashitakatta. Demo mada 3 tokuten. Ni-keta ijō no tokuten o agete, J 1 shōkaku ni kōken shitai' to chikaradzuyoku katatta.

Terjemahan

Di depan gawang, ketika ia menerima umpan terobosan dari FW Satokou, ia dengan tenang menendang ke gawang tepat dengan kaki kanan.

Itu kemajuan dari musim lalu dan mencetak dua gol musim ini. Namun, dalam empat pertandingan terakhir, kaki kiri cidera dan duduk di bangku cadangan. "Saya ingin memberikan hasil jika saya keluar. Tetapi saya masih memiliki 3 poin. Saya ingin berkontribusi lebih dari J1 dengan mencetak lebih dari 2 digit," katanya dengan kuat.

(Koran Asahi, 21 April 2019)

Pada kalimat sebelumnya, jika dilihat dari luar wacana ada keinginan kuat dari pemain untuk mencetak gol karena pemain tersebut mengalami kemajuan sehingga berhasil mencetak 2 gol. Namun, keinginan tersebut dihalangi karena pemain mengalami cidera sehingga keinginannya yang ingin mencetak gol tersebut menjadi terhalangi. Kedua kalimat tersebut dihubungkan dengan shikashi sehingga lebih menegaskan pada semangat pemain yang mulai menurun. Oleh karena itu, dengan shikashi yang menunjukkan hal tersebut membuat paragraf menjadi koheren sehingga shikashi memiliki fungsi koherensi wacana (Nakajima, 2009).

Untuk mengalihkan topik dari kemajuan ke kesulitan yang dialami, maka paragraf tersebut menggunakan shikashi. Dengan demikian, konjungsi shikashi memiliki sebagai pembatas wacana (Nakajima, 2009) untuk mengalihkan topik.

Shikashi dapat membuat pembaca menduga dan mendapatkan fakta baru mengenai kesulitan pemain maka hal ini dapat menarik minat atau perhatian pembaca. Dengan demikian, maka shikashi memiliki fungsi menarik minat atau perhatian pembaca (Nakajima, 2009).

Konjungsi demo menunjukkan bahwa dari semangatnya sedikit menurun karena cidera ke semangatnya mulai kembali karena poinnya masih 3 , maka disana terlihat pertentangan dari dua kalimat. Dikarenakan demo menunjukkan nuansa tersebut, maka kedua kalimat menjadi koheren sehingga memiliki fungsi sebagai koherensi wacana (Nakajima, 2009).

Pada kalimat kedua juga memberikan penjelasan tambahan yang menguatkan kalimat sebelumnya. Dengan demo menandai adanya penjelasan tambahan tersebut, maka demo memiliki fungsi untuk menandai kelanjutan (Nakajima, 2009).

Konjungsi demo pada kalimat tersebut menunjukkan adanya keraguan bisa atau tidak mencetak hasil yang lebih baik karena saat ini masih 3 poin. Dari hal tersebut dapat dikatakan bahwa narasumber merasa ragu untuk mendapatkan hasil poin yang lebih tinggi melihat poinnya yang saat ini masih rendah. Dengan demikian, maka konjungsi demo berfungsi untuk menandai adanya keraguan pada wacana dimana hal ini sesuai dengan teori Nakajima (2009).

\section{Data 2}

Tozawa shōgakkō 4-nen 26-nin ga 'Mogamigawa funauta' o hirō shi, ōkina hakushu o uketa. Kankō-sen ni shijō shita Ōkawa aoba-kun (9) wa 'kinchō shimashita. Kore hodo taisei no otona no maeda to wa omowanakatta. Demo hakushu wa sugoku kimochiyokatta' to hanashita.

Terjemahan

Sekolah Dasar Tozawa 4 tahun 26 orang menunjukkan "Mogamigawa funauta" dan menerima tepuk tangan meriah. Penumpang perahu pariwisata mengatakan 'Aku gugup. 
Aku tidak berpikir dapat berasa di depan banyak orang dewasa. Tapi, aku sangat senang dengan tepuk tangan yang diberikan."

(Koran Asahi, 24 April 2019)

Kalimat pertama menyatakan rasa gugup lalu dilanjutkan dengan demo yang menunjukkan rasa senang karena tepuk tangan, maka dapat dilihat bahwa kedua kalimat tersebut berlawanan sehingga dihubungkan dengan demo. Dengan adanya demo menunjukkan sisi positif atau kesan positif narasumber pada kalimat kedua, maka konjungsi demo memiliki fungsi koherensi wacana (Nakajima, 2009).

Kalimat kedua terdapat demo yang menunjukkan bahwa ada kesan lain selain gugup yaitu narasumber merasa senang karena tepuk tangan. Jadi, demo menunjukkan bahwa ada sisi positif dari yang dirasakan narasumber berupa adanya perbaikan atau kelanjutan terhadap kalimat sebelumnya. Dengan demikian, maka demo berfungsi sebagai penanda kelanjutan, hal ini sesuai dengan teori Nakajima (2009).

\section{Data 3}

Tōsen kara ichi yoaketa 22-nichi asa, shinai no jimusho de shuzai ni ōjita Tagami-shi. Yaku 8 man 6 sen-pyō o eta koto ni tsuite kika re, 'tokuhyō-ritsu ga 50-pāsento o koeta no wa kokorodzuyoi. Machi no kiban-dzukuri o katachi ni shite ikitai' to hōfu o katatta.

...Shikashi, 8-nen mae ni eta yaku 15 man-pyō kara wa ōhaba ni tokuhyō o herashita. Tagami-shi wa ' (ōgata jigyō nado ni) zuibun rikai shite kureta kanshoku wa attaga, hihan wa shinshi (shinshi) ni uketometai. Setsumei no shikata mo kufü shite iku' to nobeta.

Terjemahan

Tuan Tagami yang menanggapi wawancara di kantor di kota pada pagi hari tanggal 22, sehari setelah menang. Ketika ditanya tentang telah menerima sekitar 86.000 suara, "Saya yakin bahwa tingkat suara melebihi $50 \%$. Saya ingin membentuk fondasi kota," katanya dengan berambisi.

...Namun, jumlah suara telah turun secara signifikan dari sekitar 150.000 suara yang diperoleh delapan tahun lalu. Tuan Tagami mengatakan bahwa "Saya merasa memiliki banyak pemahaman (dalam bisnis berskala besar, dll.), tetapi saya ingin menerima kritik yang sebenarnya. Baik dari cara menjelaskan maupun metode."

(Koran Asahi, 23 April 2019)

Kedua paragraf tersebut berlawanan karena paragraf sebelumnya berisi peningkatan suara, sedangkan paragraf selanjutnya menunjukkan bahwa ada hal dibalik peningkatan suara bahwa sebenarnya suaranya menurun dibandingkan dengan 8 tahun lalu. Dengan ini maka shikashi menunjukkan bahwa ada fakta dibalik kenaikan suara tuan Tagami. Hal ini membuat maksud penulis yang ingin disampaikan menjadi terlihat sehingga shikashi yang menandai hal tersebut memiliki fungsi koherensi wacana (Nakajima, 2009).

Kalimat kedua mengenai penurunan suara dimana hal ini adalah suatu pengalihan topik dari kalimat sebelumnya yang menjelaskan kenaikan suara. Dengan ini maka, shikashi berfungsi sebagai pembatas wacana (Nakajima, 2009).

Penurunan suara Tagami yang ditandai dengan shikashi membuat pembaca ingin mengetahui hal dibalik penurunan tersebut, tetapi kelanjutan dari fakta penurunan suara tersebut tidak dilanjutkan. Penulis hanya menambahkan tanggapan dari Tagami, maka tidak sesuai dengan kelanjutan yang diharapkan pembaca mengenai kelanjutan fakta sebelumnya. Dengan ini maka, shikashi tetap dapat menarik minat atau perhatian pembaca (Nakajima, 2009), tetapi tidak terlalu kuat.

\section{Data 4}

4 Tsuki 1-nichi ni shin gengō ga happyō sa reru to, dōkande wa 'rei wa' ni chinanda ikimono no tenji o kentō. Aru shokuin ga 'uchi wa shiiku shite inaiga, Kagoshima no kinkai ni kakureiwagani to iu kani ga iru' to teian shita. Tokoroga hiruma wa sugata o misenai ue ni shunbin. 'Hokaku wa muzukashidarou to tenji o akirame kakete ita' to sasaki akira kanchō (52). 


\section{Terjemahan}

Ketika era baru diumumkan pada 1 April, museum pameran mempertimbangkan hewan yang berkaitan dengan 'reiwa'. Ada seorang penjual yang memberikan saran "Hewan milik saya tidak berkembang biak, tetapi ada seekor kepiting yang disebut 'kakureiwa gani' di dekat laut Kagoshima". Namun, pada siang hari hewan itu tidak terlihat dan cepat/lincah. "Saya hampir menyerah menangkapnya karena sulit", kata sutradara Sasaki Saki, 52.

(Koran Asahi, 30 April 2019)

Tokoroga maka menunjukkan fakta yang tidak diharapkan dari kalimat sebelumnya bahwa dengan karakteristik kepiting yang demikian maka sulit untuk digunakan. Oleh karena tokoroga menunjukkan hal tersebut maka paragraf menjadi koheren sehingga memiliki fungsi menunjukkan koherensi wacana (Nakajima, 2009).

Dengan tokoroga yang menjelaskan kekurangan dari kepiting sehingga sulit digunakan ini tidak sesuai yang diharapkan pembaca seperti sebelumnya sehingga hal ini dapat menarik minat pembaca. Maka dengan adanya tokoroga dapat menarik perhatian pembaca terhadap wacana, hal ini pun sesuai dengan teori Nakajima (2009).

Pada kalimat selanjutnya memperjelas karakteristik dari kepiting tersebut sehingga dapat dijadikan sebagai penjelasan tambahan dari kalimat sebelumnya. Dengan ini maka, konjungsi tokoroga berfungsi sebagai penanda kelanjutan (Nakajima, 2009).

\section{Data 5}

Saikin de wa 'neko no shima' to shite shira reru yō ni nari, neko to no fureai ya iyashi o motomete otozureru hito mo fueta. Tada, neko no esa-dai ya chiryō-hi nado wa tōmin-ra ga jibara de nenshutsu. Futan mo chīsakunai tame, ichi kankō kyōkai wa tōmin-ra to torikumu 'Fukajima purojekuto' no hitotsu to shite, zukan seisaku to kikin sōsetsu o kikaku shita.

Terjemahan

Baru-baru ini, ada sebuah 'pulau kucing' yang telah dikenal, dan semakin banyak orang datang untuk mencari dan berinteraksi dengan kucing. Namun, penduduk pulau mengeluarkan biaya sendiri untuk perawatan dan makanan kucing. Untuk meringankan beban, asosiasi pariwisata kota bekerja sama dengan penduduk pulau membentuk "Proyek Fukashima" merencanakan penggalian dana dan pembuatan buku bergambar.

(Koran Asahi, 28 April 2019)

Tada yang menunjukkan bahwa penulis tidak menerima pernyataan bahwa biaya kucing dibebankan pada penduduk pulau ini, maka maksud dari paragraf tersebut terlihat sehingga menjadi koheren. Oleh karena itu, tada memiliki fungsi koherensi wacana (Nakajima, 2009).

Untuk membatasi kedua topik mengenai pulau kucing yang dilihat masyarakat pada umumnya dengan sesuatu yang terjadi dibaliknya, maka penggunaan konjungsi tada berfungsi sebagai pembatas wacana (Nakajima, 2009).

Judul dari wacana ini menjelaskan bahwa pulau Fukashima tersebut menjual buku bergambar untuk mendapat dana dukungan. Hal ini membuat pembaca berpikir alasan penjualan buku bergambar dan alasan diperlukannya dana dukungan tersebut. Hal tersebut dijawab pada kalimat kedua. Dengan adanya tada membuat pembaca menduga fakta yang dibalik judul artikel sehingga hal ini dapat menarik minat atau perhatian pembaca (Nakajima, 2009).

\section{Data 6}

Jimusho ni yoru to, dai 2 chūshajō wa nen'nai ni kansei yotei. Genzai, seibi ga susunde iruga, chūsha jitai wa kanō to iu. Kūkō ni wa tāminarubiru no shōmen ni yaku 300-dai ga riyō dekiru chūshajō ga aru. Tada, gōruden'u īku kikan no 27-nichi 5 tsuki 6-nichi wa ryō chūshajō to mo mansha ni naru kanōsei ga aru to ī, jimusho wa kōkyō kōtsūkikan no riyō o susumete iru.

Terjemahan

Menurut kantor, tempat parkir kedua akan selesai pada akhir tahun. Saat ini, pembuatannya sedang berlangsung, tetapi kemungkinan tempat parkir itu jadi. Bandara ini memiliki tempat parkir yang disediakan sekitar 300 kendaraan di depan gedung terminal. Namun, dikatakan bahwa ada 
kemungkinan bahwa kedua tempat parkir akan penuh pada 27 - 6 Mei selama Golden Week, dan kantor merekomendasikan menggunakan transportasi umum.

(Koran Asahi, 22 April 2019)

Tada menunjukkan bahwa walaupun tempat parkir baru dibuka tetapi tetap saja ada kemungkinan parkir bandara menjadi penuh saat liburan sehingga maksud yang ingin disampaikan penulis melalui tada menjadi tersampaikan. Oleh karena itu tada memiliki fungsi sebagai koherensi wacana (Nakajima, 2009).

Pada kalimat sebelumnya membahas mengenai tempat parkir yang memuat 300 kendaran. Namun, pada kalimat selanjutnya beralih fokus pada penggunaan tempat parkir saat golden week sehingga kemungkinan menjadi penuh. Untuk menghubungkan kedua pembahasan tersebut maka, konjungsi tada berfungsi sebagai pembatas wacana (Nakajima, 2009).

Judul wacana mengenai mengenai pembukaan parkir kedua bandara Matsumoto sehingga pembaca berharap dapat memuat semua kendaraan dengan kedua parkir. Namun, isi kalimat yang ditandai konjungsi tada berbeda dengan apa yang diharapkan pembaca dari judul wacana mengenai pembukaan parkir kedua bandara Matsumoto, dimana yang diharapkan parkir dapat memuat kendaraan saat maka hal ini menjadi menarik sehingga dapat menarik perhatian atau minat pembaca (Nakajima, 2009).

\section{Data 7}

Nihonbudōkan wa tonai no daigaku no nyūgakushiki no kaijō to naru koto ga ōku, kotoshi wa 9 daigaku ga tsukatta. Daga, 2020-nen no Tōkyō gorin pararinpikku ni muketa kaishū kōji ga konshū kara hajimaru tame, raiharu wa shiyō dekinai.

Terjemahan

Nihon Budokan sering menjadi tempat upacara masuknya universitas di Tokyo, dan sembilan universitas menggunakannya tahun ini. Namun, itu tidak akan tersedia musim semi mendatang, karena pekerjaan perbaikan untuk Olimpiade Tokyo 2020 dan Paralimpiade akan dimulai musim gugur ini.

(Koran Asahi, 12 April 2019)

Daga yang menunjukkan hal yang tidak biasa yaitu budoukan tidak bisa dipinjam universitas, maka maksud yang ditunjukkan dari wacana mengenai hal yang tidak biasa tersebut menjadi jelas sehingga wacana menjadi koheren. Oleh karena itu, daga memiliki fungsi koherensi wacana (Nakajima, 2009).

kalimat sebelumnya membahas budoukan yang banyak digunakan pada tahun ini. Namun, kalimat selanjutnya beralih fokus pada penggunaan budoukan pada tahun 2020 sehingga konjungsi yang menghubungkan kalimat tersebut berfungsi sebagai pembatas wacana (Nakajima, 2009).

\section{Data 8}

Sono Yoshimune ga shiai de yū gen jikkōda. Ikkai. 2-Ten o senkō shite nao 2 shi ichirui kara tekiji sanruida o hanatta. Rīdo o 3-ten ni hiroge, Kawai no kitai ni kotaeru katachi to natta.

...Tēpu de gurugurumaki ni sa reta migite wa itaitashĩ. Kōchābokkusude wa hidarite shika tsukaenai. Daga, hyōjō wa sukkiri to shite ita. 'Mada zukizuki wa shimasukedo, genkidesu. Omoikkiri koe o dashite moriagemasu'. Nikkori to waratta. Terjemahan

Yoshimune bisa menepati janjinya saat pertandingan. Satu kali la mencetak dua gol secara berurutan dan melakukan tiga pukulan beruntun dari waktu ke waktu. Memimpin diperpanjang hingga tiga poin untuk memenuhi harapan Kawai.

...Luka di tangan kanan Kawai dengan selotip terasa menyakitkan. Hanya tangan kiri yang dapat digunakan dalam kotak pelatihan. Namun, ekspresinya terlihat baik-baik saja. "Luka ini masih sakit, tapi aku baik-baik saja. Saya mengatakan dengan keras karena bersemangat". Itu yang dikatakannya sambil tersenyum dan tertawa.

(Koran Asahi, 3 April 2019) 
Daga yang memunculkan hal yang tidak biasa bahwa pemain terluka tetapi ekspresinya menunjukkan baik-baik saja, maka paragraf menjadi koheren dengan memahami maksud yang ingin ditunjukkan penulis. Oleh karena itu, daga memiliki fungsi koherensi wacana (Nakajima, 2009).

Kalimat yang ditandai daga memberikan perbaikan atau kelanjutan mengenai kondisi dari pemain bahwa ekspresinya baik-baik saja dan tersenyum karena adik tingkat yang sebagai penggantinya memberikan hasil yang baik dalam pertandingan. Dengan demikian, maka konjungsi daga memiliki fungsi sebagai penanda kelanjutan Nakajima (2009).

Adanya pendapat penulis mengenai ekspresi pemain yag baik-baik saja sehingga daga berfungsi sebagai penanda proses kognitif. Selain itu, penulis menggunakan daga untuk membandingkan hal yang sewajarnya terjadi dimana sebagai bentuk pengalaman yang sudah diketahui dengan peristiwa yang dilihatnya. Dengan ini maka daga menunjukkan proses berpikir kognitif (Nakajima, 2009).

Dengan daga yang menunjukkan bahwa ada sisi lain dari pemain dan menunjukkan bentuk kepercayaan pada adik tingkatnya maka, daga memiliki fungsi menarik perhatian atau minat pembaca (Nakajima, 2009).

\section{Data 9}

Ippō, yokohama shiritsu shiminbyōin (Hodogaya-ku) wa kyūkyū kyūmei sentā de kyūkan o uketsukeru. 5 gatsu 2-nichi ni omona shinryō-ka de yoyaku kanja o ukeireruga, soreigai no hi wa kihontekini kyūshin. Tadashi, keizoku chiryō ga hitsuyōna jinkō tōseki ya hōshasen chiryō nado ni tsuite wa renkyū-chū mo tsūjō-dōri taiō suru.

Terjemahan Di sisi lain, Rumah Sakit swasta Yokohama menerima kasus darurat di Pusat Penyelamatan Darurat. Kami menerima pasien janji temu di departemen medis utama pada 2 Mei, tetapi pada dasarnya ditutup pada harihari lain. Namun, dalam kasus dialisis buatan dan terapi radiasi yang memerlukan perawatan terus menerus, kami akan merespons seperti biasa bahkan selama liburan berturut-turut.

(Koran Asahi, 25 April 2019)

Dengan tadashi yang dapat menunjukkan maksud pengecualian mengenai kasus tertentu seperti perawatan radiasi dan lainnya yang dapat diterima rumah sakit pada waktu kapanpun seperti yang dijelaskan kalimat selanjutnya. Dengan ini maka, paragraf menjadi koheren sehingga memiliki fungsi sebagai koherensi wacana (Nakajima, 2009).

Kalimat kedua, topik wacana beralih pada pasien lain yang diberikan pengecualian sehingga dapat dirawat tanpa batas waktu bahkan saat libur. Dengan demikian, maka konjungsi yang menandai paragraf tersebut berfungsi sebagai pembatas wacana karena untuk membatas kedua topik yang fokusnya dialihkan (Nakajima, 2009).

\section{Data 10}

Aya Yū Masaru-kun ga Tōhō ni hairitai to itta toki, Kikuo-san wa hantai shita. 'Zenkoku kara jōzuna ko ga atsumaru. Benchi ni mo hairenai zo'. Soredemo, Aya Yū Masaru-kun no ishi wa katakatta. Chīsai koro kara, senbatsu de yūshō shita chichi no sugata o bideo de mite ita.

\section{Terjemahan}

Ketika Aya Yuu Masaru mengatakan bahwa dia ingin memasuki Toho, Tuan Kikuo menentang. "anak-anak pintar di seluruh dunia berkumpul disana, bahkan kamu tidak bisa masuk tim cadangan". Meski begitu, tekad Masaru kuat. Sejak saya masih kecil, saya menonton video ayah saya yang memenangkan seleksi.

(Koran Asahi 3 April 2019)

Dengan soredemo yang menunjukkan keinginan yang kuat dari Masaru tanpa dipengaruhi pernyataan sebelumnya, maka paragraf menjadi koheren karena maksud dari paragraf tersebut menjadi lebih terlihat. Dengan ini maka soredemo memiliki fungsi koherensi wacana (Nakajima, 2009). 
Dengan kedua kalimat tersebut memiliki sudut yang berbeda, dari penjelasan sudut pandang Kikuo dengan sudut pandang anaknya, sehingga untuk mengganti perubahan sudut pandang soredemo perlu untuk digunakan untuk membatasinya. Dengan demikian, maka konjungsi soredemo berfungsi juga sebagai pembatas wacana (Nakajima, 2009).

Pada kalimat tersebut, menurut pendapat dari penulis bahwa walaupun sudah ditentang, tetapi keinginan Masaru tetap kuat, hal ini menunjukkan adanya proses berpikir dari penulis terhadap Masaru. Dengan demikian, maka soredemo menandai adanya proses berpikir dimana sesuai dengan fungsi penanda wacana menurut Nakajima (2009).

\section{Simpulan dan Saran}

Berdasarkan data yang ditemukan, maka konjungsi demo memiliki fungsi: koherensi wacana, menunjukkan keraguan, menandai kelanjutan. Konjungsi shikashi memiliki fungsi: koherensi wacana, pembatas wacana, menarik minat atau perhatian, mengungkapkan proses berpikir. Konjungsi tokoroga memiliki fungsi: koherensi wacana, pembatas wacana, menarik minat atau perhatian. Konjungsi tada memiliki fungsi: koherensi wacana, pembatas wacana, menunjukkan minat, menarik minat atau perhatian. Konjungsi daga memiliki fungsi: koherensi wacana, pembatas wacana, menarik minat atau perhatian, menunjukkan proses berpikir kognitif. Konjungsi tadashi memiliki fungsi: koherensi wacana, pembatas wacana, menarik minat atau perhatian. Konjungsi soredemo memiliki fungsi : koherensi wacana, pembatas wacana, menunjukkan minat, perhatian, menunjukkan proses berpikir kognitif.

Dilihat dari jumlahnya, shikashi yang paling banyak digunakan karena konjungsi shikashi yang lebih jelas terlihat pertentangan dan tidak terkait pada ciri tertentu. Gyakusetsu yang paling sedikit ditemukan adalah tokoroga dan tadashi. Hal ini karena tokoroga dan tadashi memiliki ciri penggunaan yang terkait dengan aturan untuk menandai hal tertentu sehingga tidak terlalu fleksibel penggunaanya.

Fungsi penanda wacana yang paling banyak digunakan adalah fungsi sebagai koherensi wacana. Hal ini karena fungsi gyakusetsu secara teori menghubungkan kalimat berlawanan sehingga makna pada kalimat atau paragraf lebih mudah tersampaikan. Lalu, fungsi yang paling sedikit ditemukan adalah menyiratkan keraguan, hal ini karena fungsi menyiratkan keraguan lebih pada unsur rasa yang lebih sesuai dan lebih terlihat penggunaannya pada bahasa lisan dibandingkan bahasa tulis. Berdasarkan hasil penelitian, konjungsi yang paling banyak digunakan adalah shikashi karena lebih terlihat pertentangannya dibandingkan konjungsi lainnya serta tidak terkait pada aturan tertentu sehingga fleksibel. Sedangkan konjunsi yang paling sedikit ditemukan adalah tokoroga dan tadashi karena terkait dengan aturan tertentu sehingga tidak fleksibel dan kasus wacana yang berhubungan dengan aturan dari kedua konjungsi tersebut juga sedikit.

Dengan adanya penelitian mengenai fungsi gyakusetsu sebagai penanda wacana pada koran asahi online ini maka dapat disarankan beberapa hal sebagai berikut. Saran untuk pembelajar bahasa Jepang diharapkan dapat lebih memahami penggunaan konjungsi khususnya gyakusetsu karena fungsi gyakusetsu tidak hanya untuk menghubungkan kalimat berlawanan saja, tetapi pada wacana ternyata memiliki fungsi tersendiri sebagai penanda wacana. Saran untuk peneliti bahasa Jepang dapat meneliti hal serupa tetapi pada jenis konjungsi yang berbeda atau sumber data yang berbeda sehingga dapat menemukan variasi yang lebih.

\section{Daftar Pustaka}

Badara, Aris. 2012. "Analisis Wacana Teori, Metode, dan Penerapannya dalam Wacana Media”. Jakarta: Kencana Prenada Media Group.

Belicová, Jana. 2011. "Japanese Discourse Markers: An Analysis of Native and Non-Native Japanese Discourse". Diploma Thesis. Olomouc: Palacký University Olomouc.

Cook, Guy. 1989. Discourse. Oxford: Oxford University Press.

Makino, Seichii dan Michio Tsuitsui. 1995. A Dictionary of Intermediate Japanese Grammar. Japan: The Japan Times, Itd. 
Nakajima, E. (2009). Shizen danwa ni arawareru fïā - shizen danwa rokuon shiryō ni motozuite [Fillers in natural discourse: Analysis of natural conversational data]. Asia Japan Journal, 4, 1-24 tersedia pada http://www.airc.jp/docs/AJJ04 Etsuko\%20Nakajima.pdf (diakses pada 22 februari 2019)

Sudjianto dan Ahmad Dahidi. 2004. Pengantar Linguistik Bahasa Jepang. Jakarta: Kesaint Blanc. 